\title{
REFERENCES
}

Annison, E. F. (1965). In Physiology of Digestion in the Ruminant p. I85 [R. W. Dougherty, editor]. Washington, D.C. : Butterworths.

Arnold, G. W. (1966). Proc. Aust. Soc. Anim. Prod. 6, 213.

Annold, G. W. (1970). In Physiology of Digestion and Metabolism in the Ruminant p. 264 [A. T. Phillipson, editor]. Newcastle upon Tyne: Oriel Press.

Baile, C. A. (1969). Fedn Proc. Fedn Am. Socs exp. Biol. 28, 1306.

Baile, C. A. \& McLaughlin, C. L. ( 1970). F. Dairy Sci. 53, 1058.

Baile, C. A. \& Mayer, J. (1967). Am. f. Physiol. 2r3, 387.

Baile, C. A. \& Mayer, J. (r968a). Am. F. Physiol. 214, 677.

Baile, C. A. \& Mayer, J. (1968b). Y. Dairy Sci. 51, 1490.

Baile, C. A. \& Mayer, J. (1969). Am. F. Physiol. 217, 1830.

Baile, C. A. \& Mayer, J. (1970). In Physiology of Digestion and Metabolism in the Ruminant p. 254 [A. T. Phillipson, editor]. Newcastle upon Tyne: Oriel Press.

Baile, C. A. \& Pfander, W. H. (1966). Am. F. Physiol. 210, 1243.

Baile, C. A., Mayer, J. \& McLaughlin, C. (1969). Am. F. Physiol. 217, 397.

Baumgardt, B. R. (1970). In Physiology of Digestion and Metabolism in the Ruminant p. 235 [A. T. Phillipson, editor]. Newcastle upon Tyne: Oriel Press.

Bines, J. A. (1968). Proc. Nutr. Soc. 27, I5A.

Bines, J. A. \& Davey, A. W. F. (1970). Br. F. Nutr. 24, 1013.

Bines, J. A., Suzuki, S. \& Balch, C. C. $(1969)$. Br. F. Nutr. 23, 695.

Blaxter, K. L. \& Wilson, R, S. (1962). Anim. Prod. 4, 35 I.

Campling, R. C. (1966). F. Dairy Res. 33, 13.

Campling, R. C. (1970). In Physiology of Digestion and Metabolism in the Ruminant p. 226 [A. T. Phillipson, editor]. Newcastle upon Tyne: Oriel Press.

Campling, R. C. \& Freer, M. (1 g66). Br. F. Nutr. 20, 229.

Campling, R. C., Freer, M. \& Balch, C. C. (1962). Br. F. Nutr. 16, 115.

Campling, R. C., Freer, M. \& Balch, C. C. (1963). Br. F. Nutr. 17, 263.

Comline, R. S., Silver, I. A. \& Steven, D. G. (1969). In Handbook of Physiology. Alimentary Canal. Sect. 6, Vol. 5, p. 2647 [C. F. Code, editor]. Washington, D.C.: American Physiological Society.

Conrad, H. R., Pratt, A. D. \& Hibbs, J. W. (I 964). Y. Dairy Sci. 47, 54.

Dinius, D. A. \& Baumgardt, B. R. (1970). F. Dairy Sci. 53, 3 I I.

Dowden, D. R. \& Jacobson, D. R. (1960). Nature, Lond. 188, 48.

Forbes, J. M. (1969). F. agric. Sci., Camb. 72, 119.

Forbes, J. M. (I970). Br. vet. 7. 126, 1.

Freer, M. \& Campling, R. C. (1963). Br. F. Nutr, 17, 79.

Graham, N. McC. \& Williams, A. J. (1962). Aust. F. agric. Res. 13, 894.

Greenhalgh, J. F. D. \& Reid, G. W. (1967). Nature, Lond. 214, 744.

Holder, J. M. (1963). Nature, Lond. 200, ro74.

Kennedy, G. C. (1966). Br. med. Bull. 22, 2 I6.

Lamberth, J. L. (1969). Aust. F. exp. Agric. Anim. Husb. 9, 493.

Leaver, J. D., Campling, R. C. \& Holmes, W. (r969). Anim. Prod. r1, г r.

Martin, F. H. \& Baile, C. A. (1970). F. Anim. Sci. 31, 248.

Minson, D. J. (1963). F. Br. Grassld Soc. 18, 39.

Montgomery, M. J., Schultz, L. H. \& Baumgardt, B. R. (1963). f. Dairy Sci. 46, 1380.

Pearce, G. R. (1967). Aust. F. agric. Res. 18, x 19.

Simkins, K. L., Suttie, J. W. \& Baumgardt, B. R. (1965). F. Dairy Sci. 48, 1635.

Tayler, J. C. (1959). Nature, Lond. 184, 2021.

Thye, F. W., Warner, R. G. \& Miller, P. D. (1970). J. Nutr. 100, 565.

Ulyatt, M. J. (1965). N.Z. 7 l agric. Res. 8, 397.

Warner, R. G. \& Bhattacharya, A. N. (1968). F. Dairy Sci. 5r, rogr.

Weston, R. H. (1966). Aust. F. agric. Res. r7, 939.

\section{The regulation of body-weight in man}

\section{By R. PAssmore, Department of Physiology, University of Edinburgh}

The words 'regulate' and 'control' would appear to be used on our programme, as if they were synonymous. I think it helps if they are distinguished and each is 
defined by Brobeck (1965) in his book on Physiological Controls and Regulation.

'The word 'control' is sometimes used interchangeably with regulation, but there are good reasons for distinguishing between the two terms. Control describes management. For a physiological exchange it is management of a rate of functioning. With reference to blood pressure, a control of heart rate and stroke volume and a control of peripheral blood flow are required for regulation of the amount of blood within the arterial system and thus for regulation of blood pressure. Partial pressure of respiratory gases within body fluids is regulated; rate of oxygen consumption and of pulmonary ventilation are controlled. Body temperature is regulated - or, at least, the temperature of some idealized and possibly theoretical mechanism in the body is regulated; rate of heat production in muscle and rate of heat loss from skin and respiratory passages are controlled. Food intake is controlled; loss of heat is controlled; work output is controlled; but energy exchange may be regulated in that the energy content of the body tends to remain constant. But perhaps this is not a regulation after all, because we do not know of the existence of any specialized cells capable of responding to changes in energy content or to any variable proportional to this content. These examples are given to illustrate the differences in usage of the words 'regulation' and 'control'; it is apparent that controls are required to achieve regulation.'

I am going to talk about regulation of body-weight and energy reserve, and control of the intake of food and control of the output of energy.

\section{The regulation of body-weight}

What is regulated? In any adult human body, the total weight and the weight of its chemical components, all ultimately derived from the food, remain constant within definable limits. Total body water, protein, potassium, sodium and calcium are regulated by specific control mechanisms about which something is known and in some cases these mechanisms are interrelated. The content of adipose tissue also varies little, although it obviously depends on the dietary intake. But the constituent which is primarily regulated is not known. It might be the total reserve of energy (fat plus carbohydrate), the total lipid or total triglyceride. Turnover studies indicate that in adipose tissue three stores of triglyceride, short-, medium- and longterm can be distinguished; these perhaps may each be regulated independently.

How are changes in content detected? This is anybody's guess. The hypothalamic centres receive information from the blood and from afferent nerves. Professor Hervey has already indicated how the centres might be sensitive to a chemical indicator.

Nerves are not conspicuous in adipose tissue, but the action of noradrenaline in promoting lipolysis in vitro is well established. It is orthodox to teach that under physiological circumstances lipid mobilization is brought about largely by noradrenaline liberated from sympathetic nerve endings in adipose tissue. Perhaps visceral afferent fibres carried in sympathetic nerves convey information about the state of distention of adipose tissue cells to the hypothalamic centres. 
How sensitive is the regulatory mechanism? There are two answers to this question. The long-term regulation is very precise; the short-term is rough. I well remember, Mr Chairman, when I was first introduced to you at a meeting of the Biochemical Society in Oxford, 35 years ago. Our combined weight then and now would have been the same, just about $\mathrm{I} 20 \mathrm{~kg}$. Yet in the interval we must have eaten between us some $40 \mathrm{Mg}$ of food, the amounts being accurately controlled so as to maintain our small stores of adipose tissue constant. This figure is important in that it emphasizes how very small a degree of imbalance leads to gross obesity.

Another illustration may be given. A healthy man or woman who either eats an extra half slice of bread $(5 \circ \mathrm{g})$ at breakfast or takes his car to work instead of walking (Io min each way) goes into a positive energy balance of $50 \mathrm{kcal} / \mathrm{d}$. If there are no compensatory changes, he or she will store in ro years an extra $20 \mathrm{~kg}$ of triglyceride and be seriously obese. It is not necessary to be a glutton to become obese.

On the other hand, personal experience and numerous surveys indicate that energy intake and energy expenditure are not balanced over a $24^{-h}$ period. Most of us can recall a weekend spent relaxing with pleasant company and with the services of a good cook. We can enjoy sitting around and eating $3500 \mathrm{kcal} / \mathrm{d}$ for at least $2 \mathrm{~d}$. On the other hand, if things are going well at work and we are really busy and interested, we may subsist on coffee and snacks providing $1000 \mathrm{kcal} / \mathrm{d}$; it may be 2-3 d before we have time to feel hungry and eat a good meal.

Surveys in which energy intake and expenditure have been assessed simultaneously show that input and output are often not balanced over $\mathrm{I}$ or $2 \mathrm{~d}$, but that they nearly always are over a 7 -d period.

\section{Control of energy output}

Homo sapiens has mechanisms which enable him to survive long periods of partial food restrictions. This he does primarily by reducing physical activity and all muscular movement to a minimum and by the reduction in basal metabolism consequent on the atrophy of the tissue. This is an adaption, not a regulation; as man and indeed all mammals have evolved in environments where the food supply was often uncertain, the development of such adaptive mechanisms was essential for survival of the species.

Energy output is divided into two components: (I) that used by skeletal muscles in the mechanical work of movement and posture and (2) that used by the resting tissues for maintenance, the basal metabolism.

The former is of course determined by the nature of an individual's life and can be consciously increased or decreased. It is customary to regard this energy as expended in 'work' and non-adjustable, and that variations in energy expenditure are met by corresponding control of food intake. We work and then eat. This Anglo-Saxon attitude to life does not take into account the possibility that a man may eat to excess from enjoyment of food and then remove the excess energy by recreations involving muscular activity. We may eat and then play. This idea probably seems strange to industrious nutritionists. It would be difficult in our 
complicated adult society to determine whether food or physical activity comes first and which follows and acts as the control in regulating the energy reserves. My guess is that I and you also $\mathrm{Mr}$ Chairman, if you will excuse me, overeat every evening, and take it out of ourselves pounding around on our feet the next day. We both feel a need to walk and that feeling may well be a control mechanism that others lack.

In most people in our modern societies, muscular activity takes up less than half of the total energy output. The rest is utilized in the basal metabolism. Of this a portion, certainly less than $20 \%$, is expended in the mechanical work of circulating the blood, breathing etc. The remainder is spent in maintaining electrochemical gradients across cell membranes and in the synthetic processes involved in replacing proteins and other macromolecules. In all instances the major part of the energy in nutrients is first transferred to ATP. It is unlikely that there is any way of disposing of energy except by utilizing it in the above ways and the possibility of a control mechanism regulating energy reserve is extremely unlikely. The orthodox view (Miller, I 968 ) is that 'when organisms are in long-term energy balance, energy expenditure determines the intake, and not the reverse.' This is consistent with the conception of oxidative phosphorylation. Exothermic oxidative enzymic reactions are not driven by substrate concentration, but take place when the level of high energy phosphate falls and the concentration of inorganic phosphate rises. Despite much search the only known case of hypermetabolism and uncoupling of oxidative phosphorylation in man is one patient described by Ernster \& Luft (1964). That there should be an enzymic control mechanism for burning off excess substrate is contrary to all modern vicws of energy transduction in cells. There are no sound experimental data suggesting any such control mechanism in mammals.

However, there are alternative pathways for the metabolism of nutrients in the tissues and these are associated with differing thermodynamic efficiencies. The use of these pathways may explain part of the specific dynamic action of some nutrients. It is also possible that they provide signals affecting input.

\section{The control of input}

$\mathrm{Mr}$ Chairman, on the subject of the drive to eat and appetite, there is nothing I can add to your admirable Rolleston lecture given to the Royal College of Physicians on $5^{\text {th }}$ May 1953. A fall in blood sugar, a drop in body temperature or the contractions of an empty stomach all promote behavioural activity leading to feeding. These mechanisms of control were no doubt essential for the survival of the primitive hunting man as described by Morris (1967) in The Naked Ape, but probably play little or no part in controlling the food input of Homo sedentarius of contemporary society. I cannot remember when I was last really hungry and our feeding behaviour is determined by habit and custom. The arts of our cooks and food chemists stimulate appetite and often make us feed when there is no physiological need for food intake.

'Most animals, and certainly man, do not eat continuously even if they get the 
chance. They stop, I suggest, because food is one of the oldest and greatest sedatives.' (McCance, 1953). This is, in my opinion, an important point. The relevant question is, Why do we stop eating? The lecture goes on: 'If the effect of food is to replenish nerve cells with oxidisable, osmotic or structural materials, it is possible to explain not only the effects of a single meal but also the sustained voracity of the really undernourished ... At present these ideas are but idle thoughts'.

\section{The specific dynamic action of food}

Booth \& Strang (1936) published experiments suggesting that satiety was associated with a rise in body temperature caused by the specific dynamic action of a meal (beefsteak) and that this mechanism was less sensitive in obese than in thin people. Their paper is not convincing and Passmore \& Ritchie (1957) who tried to repeat their results with only partial success concluded that "to measure accurately the small changes of body temperature after a meal, a most exacting technique would appear necessary'. A reinvestigation of this problem, using the much better instrumentation now available, might be worth while.

That the metabolic rate may be raised by as much as $30 \%$ after a meal is well known. The increased oxygen consumption and heat output after food is due in part to the secretory work of the digestive glands and in part to chemical transformation of the nutrients absorbed from the gut into forms which can be utilized as fuels by the tissues. Thus, amino acids have to be converted into glucose and keto acids before these can be utilized as a source of energy. These processes require ATP and the utilization of amino acids as fuel is correspondingly less efficient. Glucose may be utilized direct as fuel, in which circumstance complete oxidation to $\mathrm{CO}_{2}$ and water is associated with the net production of $38 \mathrm{~mol}$ of ATP/mol of glucose. Alternatively, it may first be converted into triglyceride and the latter subsequently utilized. There are many steps involved in these conversions and if glucose is utilized in this way the net production of ATP is less than if glucose is used direct and is about $32 \cdot 75 \mathrm{~mol}$ of $\mathrm{ATP} / \mathrm{mol}$ of glucose. This relatively inefficient use of glucose could be a means whereby part of a dietary excess is disposed of.

\section{Metabolism in the obese state}

There is now good evidence that the obese state favours lipogenesis and the use of lipid as a primary fuel for the tissues rather than glucose (Gordon, 1970). This evidence is now summarized.

(I) After an overnight fast the level of free fatty acids in the blood is higher and the respiratory quotient is lower on average in obese than in thin persons.

(2) The fasting level of blood insulin is correlated with the amount of adipose tissue present, being higher in the obese. This may be a response to impaired glucose utilization. Many obese persons become diabetic but there is no failure of insulin secretion, at least in the early stages of the disease.

(3) Adipose tissue both from human obese subjects and genetically obese mice shows increased lipogenic activity in vitro. 
(4) Obese subjects make greater use of the hexose monophosphate pathway so providing $\mathrm{NADPH}_{2}$ which is needed for synthesis of fatty acids. The evidence for this is that if obese and lean subjects are given glucose labelled in the $C_{1}$ and $\mathrm{C}_{6}$ positions, a larger proportion of the labelled $\mathrm{C}_{1}$ appears in the expired air of the obese than in the normal subject. The $\mathrm{C}_{1}$ carbon atom is primarily involved in the oxidation of glucose via the hexose monophosphate pathway.

(5) Obese patients have a diminished urinary excretion of the adrenal androgen, dehydroepiandrosterone. This hormone inhibits the activity of glucose-6-phosphate dehydrogenase which is involved in the first stage of the hexose monophosphate pathway.

However, it is not clear whether any of these changes are the cause or the consequence of the obese state. None of them allows a sharp demarcation of the obese from the non-obese. There is no evidence that the specific dynamic action is less well-marked in the obese than in normal subjects.

Homo sapiens evolved in an environment in which the food supply was often scarce. He learnt to adapt to this and is able to survive when his food intake is reduced to about half the normal amount. It is only recently that a significant proportion of the species has lived in an environment with an abundant supply of food, which can be obtained without physical effort. There is no evidence of any regulatory mechanism which can protect him against overeating and the consequent storing of excess energy as fat. Although, as indicated above, there are possible mechanisms whereby a higher proportion of dietary energy could be dissipated as heat without being associated with the corresponding amount of work, it seems very unlikely that obesity arises as a result of any such changes. In the vast majority of cases of human obesity, the condition appears to arise from changes in behavioural activity which are not compensated by any physiological control system.

\section{REFERENCES}

Booth, G. \& Strang, J. M. (1936). Archs intern. Med. 57, 533.

Brobeck, J. R. (1965). In Physiological Controls and Regulation. p. 5 [W. S. Yamamoto and J. R. Brobeck, editors]. Philadelphia: Saunders.

Ernster, L. \& Luft, R. (1964). Advances in Metabolic Disorders r, 95.

Gordon, E. S. (1970). Advances in Metabolic Disorders 4, 229.

McCance, R. A. (1953). Lancet, ii, 685.

Miller, A. T. (1968). Energy Metabolism. Philadelphia: Davis.

Morris, D. (1967). The Naked Ape. London: Jonathan Cape.

Passmore, R. \& Ritchie, F. J. (1957). Br. F. Nutr. II, 79.

Food intake and growth in the newly-born

By Eusie M. Widdowson, Dunn Nutritional Laboratory, Infant Nutrition Research Division, University of Cambridge and Medical Research Council

So long as it is in the uterus the foetus receives its supplies of nutrients and energy from the blood reaching it from its mother through the placenta. The 